\title{
Marketing Communication and Synergy of Pentahelix Strategy on Satisfaction and Sustainable Tourism*
}

\author{
Nurul CHAMIDAH ${ }^{* *}$, Budi GUNTORO $^{* * *}$, Endang SULASTRI $^{* * * *}$ \\ Received: January 16, 2020 Revised: February 02, 2020 Accepted: February 06, 2020.
}

\begin{abstract}
This study aims to present explicit findings from an internal perspective, namely the interaction patterns of marketing communication between pentahelix elements and testing the expectations of tourists towards tourism activities through a simulation model between variables. This study is divided into two methods of analysis, namely qualitative explorative, where the study aims to invest in communication patterns and patterns of interaction between pentahelix stakeholders in Sitiwinangun Tourism Village, West Java, Indonesia with involve 17 informants who came from pentahelix elements (Government, academics, community, business and media). Second, quantitative method to measure the extent of effectiveness rather than collaboration activities and the role of marketing communication to tourist satisfaction is done by an analytical approach involving 30 tourists through customer satisfaction surveys. The results of this study illustrate that the involvement of each pentahelix element has not been maximized. The pattern of interaction and communication between elements also shows the gap between interests, expectations, and reality. This study provides a real picture that to realize a tourism program that is profitable, holistic, and sustainable requires collaboration that is wrapped with transparent and interactive communication patterns. The marketing communication concept approach combined with collaboration theory between stakeholders can be useful for sustainable tourism.
\end{abstract}

Keywords : Pentahelix, Marketing Communication, Collaborative, Mix-Method

JEL Classification Code: L83, M30, O1.

\section{Introduction}

Communication in a marketing perspective plays a vital role in realizing what the company aspires to be, namely an

*Thanks to Universitas Gadjah Mada, and the Indonesia Endowment Fund for Education (Lembaga Pengelola Dana Pendidikan, LPDP) of Ministry of Finance.

${ }^{* *}$ First Author. Doctoral Student, Department of Extention \& Communication Development, Postgraduate School, Universitas Gadjah Mada, Lecturer of Universitas Muhammadiyah Cirebon, Indonesia [Postal Address: Bulaksumur, Caturtunggal, Kec. Depok, Sleman, Daerah Istimewa Yogyakarta, 55281, Indonesia] Tel: +62 81324571153. Email: chamidah.rul18@gmail.com

${ }^{* * *}$ Corresponding Author. Professor, Department of Livestock Social Economics, Faculty of Animal Science, Universitas Gadjah Mada, Indonesia. Email: budiguntoro@ugm.ac.id

****Associate Professor, Department of Livestock Social Economics, Faculty of Animal Science, Universitas Gadjah Mada, Indonesia.

(c) Copyright: The Author(s)

This is an Open Access article distributed under the terms of the Creative Commons Attribution NonCommercial License (https://creativecommons.org/licenses/by-nc/4.0/) which permits unrestricted noncommercial use, distribution, and reproduction in any medium, provided the original work is properly cited. increase in sales, which will undoubtedly have a systemic impact on the company's profitability and sustainability (Martin, Javalgi, \& Ciravegna, 2020; Porcu, del BarrioGarcía, Kitchen, \& Tourky, 2019). Not much different from the activities and communication patterns that are formed in marketing tourism destinations to prospective tourists also require effective communication in addition to an optimal management strategy (Wu, 2018; Kozak \& Buhalis, 2019; Yousaf \& Xiucheng, 2018). Indeed, it takes a good, useful and deep interaction pattern to inform, persuade and remind prospective tourists both domestic and foreign directly or indirectly about the features and advantages of a tourist attraction (Lee \& Syah, 2018; Mustafa, 2019). An overall pattern of interaction involving all parties, on the other hand, requires a long struggle and is a challenge to unite a variety of different perceptions that aim to gather interests in resolving conflicts of interest between each stakeholder (Dorn, 2011).

Pentahelix concept that has been conceived in various studies in Indonesia (e.g., Aribowo, Wirapraja, \& Putra, 2018; Halibas, Sibayan, \& Maata, 2017; Yuningsih, Darmi, 
\& Sulandari, 2019; Soemaryani, 2016). Where the purpose of pentahelix in the Indonesian tourism sector contains the urgency of the synergy of the role of government, academia, society, business, and media as the main composition to realize the holistic, compelling tourism idea and summarize all elements of interest.

Tourism in various parts of the world is proven to be a sector that contributes a substantial income to a region and country besides the manufacturing industry, natural resource products, and the tax sector (Lee \& Syah, 2018; Mustafa, 2019). Specifically, the industry that moves in the tourism sector is an advantage given by God that requires professional, innovative touches to make the gift of God not in vain and bring sustainable profits. Greece, Cuba, Hawaii, Ibiza one of the many countries or regions that rely on the tourism sector as the primary source of income which ranks number one in the order of their country's income dependence (Berrozpe, Campo, \& Yagüe, 2019; Fragoudaki \& Giokas, 2016; Hingtgen, Kline, Fernandes, $\&$ McGehee, 2015). Indonesia is an archipelago located at the latitude of the equator, the coast, mountains, air, land, and underwater is an object that can be used as a leading tourist attraction if managed professionally and in synergy with one another (Kurniawan, Adrianto, Bengen, \& Prasetyo, 2019).

To realize the idea of tourism, the government, as an actor who holds a central role, is expected to embrace various other pentahelix elements to bring the concept of tourism into reality. But the government cannot work alone; input ideas are needed, constructive criticism from multiple pillars such as academics, society, business, and media (Aribowo et al., 2018). In Indonesia, the role of academics not only requires that thinkers and scholars only provide material in the classroom and research alone, but also the implementation of science is also expected to have a direct impact on society through community service (Kusuma, Rina, \& Syam, 2018) it can be in the form of community empowerment or the provision of short or continuous training and workshops to create a better civilization in Indonesia (Kusuma et al., 2018; Suryaningnum, Hastuti, \& Suhartini, 2013).

Apart from that, the business element also cannot fight alone to carry out tourism activities without the umbrella of regulations made by the government. In short, the government for business elements is like a guidebook to ethically protecting business activities per specified corridors. On the other hand, the role and input of the community also deserve to be collected and accommodated. Because the city is an element that lives in the area of the tourist destination as the principal element that knows in detail, dealing directly with the benefits obtained or even the impact that will be caused in the future (Wang, Liu, \& Innes, 2019). As a complement that is not less important, the media as a funnel to market tourism products also plays an important role that also deserves to be accommodated and appreciated (Tan, Lee, Hew, Ooi, \& Wong, 2018; Jansson, 2018; Li, Guo, Wang, \& Zhang, 2019).

Consumer satisfaction is a hot topic alluded to in various business management studies including in research related to tourism such as research. Park, Hahn, Lee, and Jun (2018) states that efforts to increase consumer satisfaction can be achieved through the expectations received by consumers regarding satisfaction with food, satisfaction with transportation access, satisfaction with lodging and satisfaction with existing facilities at tourist sites (Mashur, Gunawan, Fitriany, Ashoer, Hidayat, \& Putra, 2019). Different from El-Adly (2019) in his research which states that the factor of consumer satisfaction in aspects of tourism and hospitality management lies in selfgratification value, aesthetics value, price, transaction value, hedonic value, and quality value (Yusuf, Nurhilalia, $\&$ Putra, 2019). The collaborative governance approach in the pentahelix perspective is the right instrument for confronting the problem. The collaborative theory approach acts as an intermediary so that pentahelix elements (media, academics, the business community, and government) can formulate the same understanding of a problem.

The dynamics in collaboration include engagement principle, namely dynamics that are often encountered and experience obstacles such as face-to-face dialogue (Ansell \& Gash, 2008; Thomson \& Perry, 2006; Emerson \& Gerlak, 2014). The second of dynamic that usually occurs in realizing collaboration is a motivational factor in which there are obstacles on the side of mutual trust, the process of legitimacy, and the guarantee of shared commitment. The third dynamic in the collaboration process is the capacity for joint action. Indeed, to realize the capacity to carry out what is agreed by the pentahelix element requires procedures and institutional arrangements that have been regulated in which the role of leadership, knowledge and resource support is often a problem to determine who is the activator for the pentahelix element (Indonesia Minister of Tourism, 2016). All pentahelix elements play a vital role in each other's fields, so to gather the whole ideas, concepts, and interests that represent each pentahelix element is certainly not an easy and fast job. So the collaborative theory approach is also required to use the communication theory approach.

Analysis of the communication role of each pentahelix stakeholder generally uses the concept by Crosby (1992) and Freeman (1999); where this approach aims to identify influences and interests, the importance relates to the power of the activity, including in it, supervision of the decisions made, and the facility implementing the operation as well as handling the negative impacts caused. 
So, it can be assumed that the combination of communication theory, collaboration theory is a wise step to look at the problems in this research holistically. So, it can be assumed that the combination of communication theory, collaboration theory is a wise step to look at the problems in this research holistically. Communication theory is a series of relationships between theoretical concepts that contain verbal or visual communication patterns connecting speakers and listeners that provide information, explanations, assessments, and estimates of human action (Pablé, 2019; Burchill \& Pavlic, 2019).

Realizing the pentahelix strategy for the tourism industry in Indonesia is a noble idea to get sustainable tourism. The definition of sustainable development is to maintain the quality and quality of survival for the next generation. Some points that can be taken to preserve the tourism sector are protecting the environment (biodiversity), preserves the essential ecological processes, facilitates and engages public participant and ensures that productivity can be sustained into the long-term future (Florek, 2012; Murdifin, Pelu, Putra, Arumbarkah, Muslim, \& Rahmah, 2018). Related to the pentahelix strategy where the role of government, academics, media, business, and society is a driving factor and stakeholders for the development of the sustainable tourism industry.

Some studies (e.g., Choi \& Sirakaya, 2005; Cárdenas, Byrd, \& Duffy, 2015; Poudel, Nyaupane, \& Budruk, 2014) confirmed that the subjective indicators that drive sustainable tourism include the role of the government and the local community. Yu, Chancellor, and Cole (2011) and McComb, Boyd, and Boluk (2016) added that several aspects need to be considered to maintain the sustainability of the tourism industry and protect each stakeholder such as perceived social cost, environmental sustainability (Tyrrell, Paris, \& Biaett, 2012), long-term planning, perceived economic benefit, community-centered economy, ensuring visitors satisfaction, Maximizing community participation. Jamal, Taillon, and Dredge (2011) stated that the academic role as part of the community that advances the tourism industry is very crucial, through approach and collaborative learning, diverse community involved service. In business aspects related to stakeholder theory and sustainable tourism Björk, (1997) suggests that the concept of ecotourism should not be used in marketing, but instead sustainable tourism. Eventhough the international competition is rigid, to counterbalance the backlash of being small companies with low profit margins, tourism companies should increase collaboration, create networks and invest in relationship marketing.

Departing from the topics that have been described, the key to success in realizing these ideals is undoubtedly preceded by an interactive communication pattern and goes both ways between each element. Meanwhile, to measure the effectiveness of the efforts that have been carried out can be measured through how represented the expectations and satisfaction of consumers in traveling. This study seeks to present an explicit finding from an internal perspective, namely the pattern of interaction of marketing communication between pentahelix elements, then quantitatively explanatory measure of tourist expectations of tourism activities through a simulation model between variables.

\section{Literature Review}

In realizing pentahelix, which involves five essential aspects, as explained in the introduction sub-chapter, an individual approach is needed to bridge the five elements so that they become a sophisticated and synergetic unit. This study maps research approaches through a variety of theoretical perspectives. Like the theory of participation, by definition, this theory focuses on activities that evoke feelings and include individuals/groups in an event (Wondirad \& Ewnetu, 2019). In connection with community participation in the development of the sustainable tourism industry, engagement is the active involvement of the community in the process of determining the direction of the tourism industry development policy strategy implemented by the government. The concept of community participation is divided into three sub-categories, namely: political participation, social participation, and citizenship participation. In the case of the development of the tourism industry the role and involvement of the community can provide opportunities and more excellent opportunities to maximize the potential of untapped areas

Besides, related to tourism development, stakeholder involvement is required, which is summarized in stakeholder theory. Definition of stakeholders, according to Freeman (1999), is any group or individual that can influence or be affected by the achievement of organizational goals. Stakeholder theory is a theory that describes which parties the company is responsible for. The application of the concept of sustainable tourism to the planning and development process is an essential matter for discussing the main compelling tourist destinations. Indeed, the planning process that has been arranged in the management cycle is a necessary foundation in terms of the implementation of the roles and functions of the "POAC" management (Planning, Organizing, Actuating, and Controlling). Planning and development process neatly arranged through the matching of Parisian theory and stakeholder theory for the development of the tourism industry provides opportunities for the development and dissemination of knowledge universally through increased 
experience (Theodoulidis, Diaz, Crotto, \& Rancati, 2017; d'Angella \& Go, 2009; Stylidis, Belhassen, \& Shani, 2014).

Indeed, participation and public opinion are needed and related to stakeholder theory because it consists of views on program development, project planning, community involvement and also various other activities which of course by involving community participation the need for the development of the tourism industry becomes more optimal. The synergy between participation theory and stakeholder theory encourages national and international collaboration in terms of tourism development, of course, the synergy between community participation in line with the interests of positive stakeholders will reduce the level of conflict between pentahelix entities in terms of tourism development (Kapera, 2018). Bridging between the interests of the stakeholders, sophisticated design is required that must pay attention to the quality structure of activity and the development of tourism (Ramón, Herrera, Sasidharan, Daniel, Herrera, Alberto, \& Hernández, 2018).

Stakeholder involvement is needed to plan and implement the program together. So that there is a symbiosis of mutualism between stakeholders, because, the stakeholders' engagement is a means to establish communication, get support from the community, collect data/ideas in carrying out organizational activities which results in sustainable decision making that is fun and accommodates the interests of all parties (Barney \& Harrison, 2018; Freeman, Phillips, \& Sisodia, 2018; Laplume, Sonpar, \& Litz, 2008). The stakeholder engagement process requires an identification process before entering a program or purpose. Identification is needed to determine the potential that is owned by stakeholders in developing tourism. This is to avoid the inaccuracy of the role or position of stakeholders that would hamper the process of developing community-based tourism to be more independent. Failure to identify an interest even from just one stakeholder will result in a process failure (Gyan \& Ampomah, 2016; Elias, 2017). Stakeholders need to be involved in decision making, even though their influence is small. Besides, stakeholders must be included in each stage of the program, not just at the initial planning stage.

The main obstacle to successful development is not because of economic factors but because of the lack of communication between decision-makers and beneficiaries (Jain \& Gandhi, 2016). Economic development requires a development communication strategy to connect one area to another, stakeholders with other stakeholders so that the tourism development system moves harmoniously towards the expected goals (Bharadwaj, 2014).

The issue of coordination and development synergy in Indonesia is still a severe obstacle in accelerating tourism development (Aribowo et al., 2018; Hidayat \& Harto, 2017;
Yuningsih et al., 2019). A contributing factor to the failure of coordination in development is sectoral egos or regional egos that have not been able to see the interests and value of more enormous benefits for the long-time. Development programs that do not coordinate well with each other make programs/projects overlap with roles and throw together responsibilities (Aribowo et al., 2018). Miss-understanding enables development projects to be slow to be reached and can even lead to failure. Besides, other problems faced by Indonesian tourism are that they have not explored their potential, there is no proper formulation, and they have not carried out the correct implementation process in the development of Indonesian tourism (Thaib, 2016). Seeing this issue the Indonesia Ministry by Tourism minister regulation No. 14 of 2016 regarding guidelines for sustainable tourism destinations by developing the pentahelix concept of tourism stakeholders consisting of Academics, Business, Community, Government and Media (ABCGM) so that tourism problems and development are resolved together with all stakeholders with a solid, speed and smart way (Indonesia Minister of Tourism, 2016)

The next challenge that arises is how the development of tourism villages can be built together. Public awareness to find out and explore the potential of their village could have the opportunity to become a tourist village that requires stimulus ideas from both inside and outside. Therefore, it is indispensable to design a tourism village development with the involvement of stakeholders so that the Ministry of Tourism's previous aspiration to form the most extensive and most varied tourism village in the world can be realized.

\section{Research Methods and Materials}

\subsection{Informant Criteria}

Through qualitative testing, the number of informants in this study numbered 17 people representing each element of pentahelix (Academics, Business, Society, Government, and Media). Furthermore, quantitative testing by taking a sample of 30 tourist visitors is illustrated as in Appendix 1. The criteria for determining the informants of the academic elements came from the university, academy, institute which concentrated in a variety of five total informants, and the community element consisted of tourism management, the community of development drivers focused on tourism, community leaders and youth. The business element consists of CSR fund companies and tourism business associations. The government element consists of the central and regional tourism ministries, the industry and trade department, the local government; the media element consists of local electronic print media and 
online news media. The sample retrieval uses the snowball sampling method with key informants who are local tourism activists and local development community leaders. The research location is the Tourism destination of Sitiwinangun Tourism Village, Cirebon Regency, West Java, Indonesia.

\subsection{Measurement and Research Design}

In the first phase, the research phase was carried out data collection through observation, interviews, and documentation studies. The second phase was carried out as a focus group discussion to explore data on stakeholder involvement in the development of tourist destinations through the stages of planning, implementation, evaluation, and enjoying the results. Instrument for measuring the role of stakeholder pentahelix concepts and programs consisting of research and development, community development, capacity building for academics; business partnerships and code of conduct for business stakeholders; Tourism attraction development programs, community development Ethically protective, small-scale business and inclusive tourism for community stakeholders; regulatory programs, stimulus packages and incentives, and infrastructure for government stakeholders; Paid media programs and promotions and reputation for media stakeholders.

This study uses a mix method approach between explorative qualitative and quantitative explanatory through several stages of testing, namely: Qualitatively: 1). FGD phase through observation, interviews, and documentation 2). SWOT Analysis Phase to determine the imbalance between role activities and ideal needs for the perfect tourist destination development program 3). Analysis of role involvement and communication patterns between pentahelix elements. Quantitatively this study adopts and modifies research by Park et al. (2018): a Sampling of respondents came from tourist sites totaling 30 eligible respondents with various age criteria ranging from 15-64 years, the number of visits in the Sitiwinangun Tourism Village, whether it was the first time or more than two times visits. The duration of stay at the tourist site. Data collection uses a questionnaire which includes the congruence between expectations and reality (Haming, Syaiful, Putra, \& Murdifin, 2019). In detail, the measurement of the questionnaire is shown in Appendix 2. The testing phase includes 1). nomological Validity, Reliability, Normality, 2). Quadrant analysis through factor testing.

\section{Results and Discussion}

\subsection{Study I}

Stakeholder analysis is carried out using the concept of Crosby (1992) by identifying the influence and importance of tourism development. Impacts related to power over activities, including in it, oversight of decisions made, and businesses implementing facilities as well as handling the negative effects caused in detail are illustrated in Appendix 3 and 4. The stakeholder analysis was carried out using the concept of Crosby (1992) by identifying the influence and interests of the development of the Sitiwinangun Tourism Village. The results of interviews with all informants are as follows:

Interest factor: Sitiwinagun Village, Cirebon Regency has all the potential of complete tourism, such as in Bali and Yogyakarta - Indonesia. This is a capital in the development of tourism that can be a motor for development and community welfare as well as an interest for academics in Sitiwinagun Village, Cirebon Regency. The Sultanate of Cirebon who has a direct role as the successor to the generation of the founder of the Cirebon regency - Indonesia so that he tries to continue to preserve the culture and art of Cirebon Regency in the form of objects (tangible) and intangible.

"Cirebon has a tourism sector that is not inferior to Bali and Yogyakarta. We (Cirebon District) have four Kraton (Empire), Taman Sari, Tomb of Sunan Gunung Jati, and Batik Trusmi. But the government does not see this as a potential to improve people's welfare. One of the possibilities not recognized by the Cirebon Regency government is the pottery created by Sitiwinangun village which began in the Majapahit kingdom and several beachtourism (Community Informant, 2019).

Sitiwinangun Tourism Village makes academics from Fine Art based universities in Indonesia as a location for research and community service. Interest in studying the potential of Sitiwinangun starting from the relics of objects and intangible objects made academics start coming to Sitiwinangun Village.

"... for tourism, for example, Desa Sitiwinangun the most unique thing to develop is Ceramics? Now for ceramics, most craftsmen try to bring ceramics back to the Majapahit era. Suppose that if we see, the jug model is still like the original. Starting from the raw material structure (brick), how to burn it is still a classic. Because if we want to develop an art, for example, Sitiwinangun, there must be something superior that doesn't exist elsewhere." (Academics informan, 2018)

Whereas from one of the universities (academic stakeholders), the form of closeness and interest in Sitiwinangun Village began with a mentoring program to 
increase pottery products in collaboration with universities, the Indonesia Ministry of SME's and the Indonesian Ministry of Industry.

"I researched all the pottery starting from Plered (ceramics from Purwakarta, West Java, Indonesia), Kasongan (ceramics from Yogyakarta, West Java, Indonesia), to Bayat (Klaten Typical Ceramics, West Java Indonesia). And specifically, for the type of Plered ceramics originating in Yogyakarta, Indonesia, I accompanied the craftsmen so they could export. Well, specifically for Sitiwinangun, Cirebon Regency is unique because its grip (tradition/customary) is still strong. Like animal mythology and color patterns. This must be maintained so that its cultural value is not lost. So if it is for the development of a tourist village, it looks like ". (Academics Informan, 2019).

"Cirebon, especially in the village of Sitiwinangun, has a lot of potentials, as the Chair of the Guides Association conducts scouting training because its market share is already large. Many guests also came from Jakarta and Bandung. In addition, souvenir shops typical of Cirebon have started to bloom. It's just that it hasn't been organized. the government also has not seen this as an opportunity". (Academic Informan, 2019).

Government Authority: The government, both on a national and village scale, has the authority to assist the community as a way to improve the welfare of its citizens. As was done by the Cirebon District Trade and Industry Office, which provided aid to artisans in Sitiwinangun Village. The form of assistance to the craftsmen is in the way of an internship program:

\section{"...We have to assist the craftsmen Sitiwinangun"} (Cirebon Trade and Industry Office, 2018).

The influence arising from the role of each pentahelix element comes from several important points that give rise to interest rather than the role played. Second, the factor of authority possessed by each component of pentahelix carries the influence and orientation of interests to develop tourism potential. Third, namely the role of the self and institutions such as pentahelix elements of academia and media where academics have the primary duties and functions, one of which is community service whose main task is regulated in Indonesian government regulations relating to workload and responsibilities of lecturers in Indonesia, one of which contains the duty of community service.

Factors that influence the relationship between stakeholders Pentahelix on the development of tourist destinations are influenced by factors limited to human resources in each Pentahelix Institution. Access to establish cooperative relations, concept paradigms that sometimes clash with programs and policies so that the tendency that occurs merely is repeating work programs in the past. Then what happens is that all the pentahelix components wait for one another, and there are no motivating factors that can start implementing the work program that has been created (Figure 1, see Appendix 4).).

The cooperation between the government and academics has been going well because the two sectors are involved in the preparation and implementation of the program. While the communication network is not active between the government and business due to the absence of regulations made by the government related to the development of tourist villages. So that the business sector is reluctant to take one action without being shaded by regulations that protect business activities.

So that the event of an ideal pentahelix to apply to the development of a tourist village is illustrated as shown in Figure 1 (see Appendix 4). Where the role of government includes regulations regarding the master plan and regulations to regulate investment, infrastructure, and empowerment for the community, business, media, and academia in a comprehensive manner, the pentahelix element of the government can form partnerships with helix media in terms of creating advertising systems and integrated marketing systems. Between helix media, the government and business are expected to establish institutional cooperation both through regulations that facilitate the business sector in terms of funding and investment as well as rules governing human resources as an asset for the tourism village. Between helix academics, business, and society that is a partnership that synergizes with each other, including the creation of planning documents through research that is useful for the business sector, research in the form of community service and empowerment.

\subsection{Study II}

The results of the qualitative study in the previous discussion (see Section 3.1) have shown internal relations and coordination between pentahelix elements that indicate conditions and patterns of interactive and non-interactive interactions. So that in constant conditions as has been stated, the second study aims to analyze and measure the extent to which the effectiveness of marketing communication patterns that have been applied to the tourist destination of Sitiwinangun Tourism Village towards tourism consumer satisfaction. Some phase are an investigation of quantitative normality and validity and then determine the factors that have a central role that triggers customer satisfaction (see Table 1 and 2).

The model in Table 1 shows that overall marketing 
communication indicators are valid for compiling variables even though they have low reliability when compared to the constituent items of tourism satisfaction variables. Whereas the component matrix in Table 5 shows that of the 30 respondents coming from tourists divided into three quadrant classes regarding the factors felt by consumers related to their satisfaction with tourism destinations in the Sitiwinangun Tourism Village.

Three components are divided into eleven classes, and dominant are three classes where the highest Initial Eigenvalues value is 30,935 , and the lowest is 11,287 . In Class I, the total component matrix is 3,093, with initial eigenvalue $=30,935$. Class II with a total value of 1,762 with initial eigenvalue $=17,625$. Class III with a total value of 1,129 with initial eigenvalue $=11,287$. Furthermore, the component matrix between variables explains the largest correlation value between each quadrant. Quadrant I is a rating component that is considered to have an identical effect between marketing communication on tourist satisfaction.

Table 1: The Goodness of Fit Assesment

\begin{tabular}{|c|c|c|c|c|}
\hline $\begin{array}{l}\text { Variables / } \\
\text { Item }\end{array}$ & $\begin{array}{l}\text { Deleted } \\
\text { Item }\end{array}$ & Validity & Reliability & Info \\
\hline $\begin{array}{l}\text { Marketing } \\
\text { Communication }\end{array}$ & \multirow{5}{*}{$\begin{array}{l}\text { MCom2, } \\
\text { MCom4 }\end{array}$} & & 0.316 & \multirow{5}{*}{$\begin{array}{c}\text { Significant } \\
\text { and valid } \\
\text { but have a } \\
\text { low reliable } \\
\text { aspect }\end{array}$} \\
\hline Mcom1 & & 0.049 & 0.530 & \\
\hline Mcom3 & & 0.013 & 0.238 & \\
\hline Mcom5 & & 0.000 & 0.027 & \\
\hline Mcom6 & & 0.001 & -0.045 & \\
\hline $\begin{array}{l}\text { Tourism } \\
\text { Satisfaction }\end{array}$ & & & 0.762 & \multirow{7}{*}{$\begin{array}{l}\text { Significant } \\
\text { and valid } \\
\text { have a } \\
\text { Medium to } \\
\text { high reliable } \\
\text { aspect }\end{array}$} \\
\hline TS1 & \multirow{6}{*}{ TS7 } & 0.000 & 0.673 & \\
\hline$T S 2$ & & 0.000 & 0.675 & \\
\hline$T S 3$ & & 0.001 & 0.721 & \\
\hline TS4 & & 0.011 & 0.739 & \\
\hline TS5 & & 0.000 & 0.698 & \\
\hline TS6 & & 0.024 & 0.826 & \\
\hline \multicolumn{4}{|c|}{ Kolmogorov - Smirnov. Normality Test $=0.200>0.05$} & Normal \\
\hline \multicolumn{4}{|l|}{$\mathrm{R}-\mathrm{Square}=0.160$} & $\begin{array}{c}\text { Have effect } \\
16 \%\end{array}$ \\
\hline \multicolumn{4}{|c|}{ KMO and Bartlett's Test $=0.001<0.05$} & Supported \\
\hline
\end{tabular}

In Quadrant I (see Figure 2) in constant conditions, the role of government promotion is felt to influence tourist satisfaction, including satisfaction with food quality (cleanliness, taste, and presentation). Satisfied with the availability of transportation, hotel prices, and FMCG products at tourist sites also gives satisfaction to tourists. As well as satisfaction with the friendliness of the local people in the tourist destination of Sitiwinangun Tourism Village.

Table 2: Component Matrix

\begin{tabular}{|c|c|c|c|}
\hline Class & Total & \multicolumn{2}{|c|}{ Initial Eigenvalues } \\
\hline Class 1 & 3.093 & \multicolumn{2}{|c|}{30.935} \\
\hline Class 2 & 1.762 & \multicolumn{2}{|c|}{17.625} \\
\hline Class 3 & 1.129 & \multicolumn{2}{|c|}{11.287} \\
\hline \multicolumn{4}{|c|}{ Component Matrix } \\
\hline Item & Class 1 & Class 2 & Class 3 \\
\hline MCom1 & .010 & -.365 & .683 \\
\hline MCom3 & -.181 & .525 & .153 \\
\hline MCom5 & -.117 & .730 & -.035 \\
\hline MCom6 & -.303 & .725 & .183 \\
\hline TS1 & .860 & .046 & .169 \\
\hline TS2 & .822 & .252 & -.088 \\
\hline TS3 & .708 & .166 & -.025 \\
\hline TS4 & .584 & .386 & .074 \\
\hline TS5 & .807 & -.200 & .162 \\
\hline TS6 & .215 & -.115 & -.731 \\
\hline
\end{tabular}

Quadrant II shows that the support of ease of access to tourist sites Sitiwinangun Tourism Village provides satisfaction for tourists. The support of lodging facilities, attractive spots destined for tourism and cleanliness, and security guarantees during the tour are things that are considered quite important to be developed for the tourist sites of Sitiwinangun Tourism Village.

Quadrant III is a crucial thing to maintain, namely the promotion of government, understanding of the local community, and satisfaction with food and drinks that exist in tourist sites.

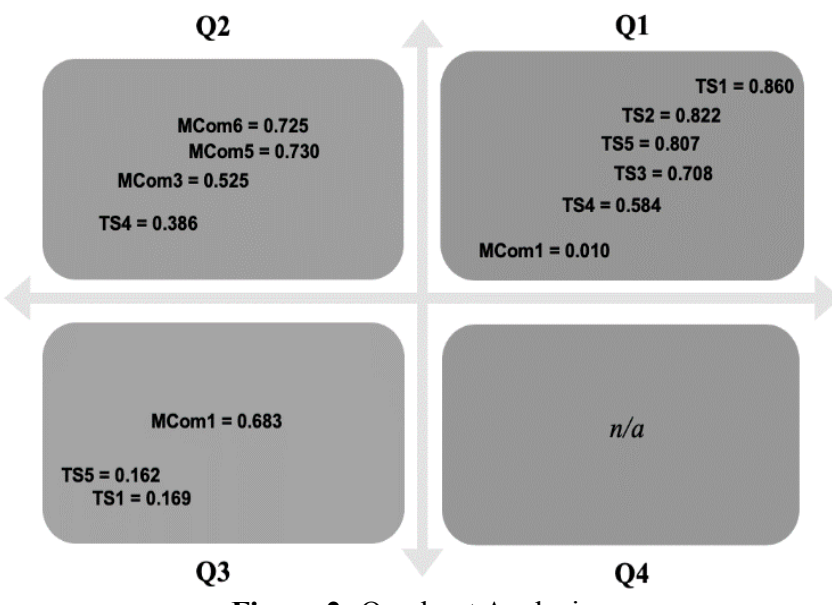

Figure 2: Quadrant Analysis 


\subsection{Discussion}

The concept of collaboration to achieve the desired goals is essential today. Of course, the availability of resources, limited authority, and also limited excellence are the reasons why collaboration is a right and effective solution for expanding networks and access. This study shows something similar that to succeed in the tourism industry amid intense competition requires the participation of all stakeholders and pentahelix elements. The government as the main actor who has full power plays a role in the formation of regulations to cover all other pentahelix elements (academics, society, media, and business). However, the limitations possessed by the government are, of course, limited in terms of budget allocation, limited in terms of concepts, and limited in terms of research and development.

The business pentahelix element naturally owns the ability to express ideas into applications in the tourism industry. Business people in their activities have advantages in terms of developing ideas turned into material benefits, the availability of business strategies, business networks, and cooperation between business people is an advantage as well as a threat to business people if it is not under of government regulations. The synergy between business and government elements is the right combination given the quite central position of the two. The government is the ruler of the waste-land, while the businessman can turn the waste-land into a profit-land. Turning wasteland into profit-land, of course, the government must have a master plan related to the development of regions and tourism areas, as well as protection for businesses through regulations to protect business activities.

The synergy of both (business - government) can meet obstacles in the field if it does not protect the interests, criticisms, and suggestions from the local community. It is considering that the community is a pentahelix element that is in direct contact with tourism activities that will be proclaimed by the government and businesses in the region. Social, economic, and cultural issues will undoubtedly be a hot topic of discussion and discussion, which, when not adequately accommodated, will produce a long debate and not find a way out. Therefore, the role of the community also contributes to neutralizing the interests between government and business. Besides, if in the future, what has been planned by the government and business elements has been realized, then the satisfied people have been accommodated by their ideas and input, of course, will also try to protect the tourism devices in their area. Therefore also, to further introduce attractions to potential tourists, of course, the role of the media is significant. No less important than the activity of tourism, in addition to aiming to gain benefits, is also aimed at the realization of research and development (R\&D) for the tourism object itself. The role of academics, in this case, holds the key as a catalyst to realize this and will also have an impact on increasing knowledge and even the development of insights and skills for pentahelix elements of society in the form of service and research.

\subsection{Theorethical Implication}

The results of this study illustrate that the involvement of each pentahelix element has not been maximized. The pattern of interaction and communication between elements also shows the gap between interests, expectations, and reality. The patterns of interaction and communication networks that are not optimal, assume that each pentahelix element feels independent. The communication patterns that have not been optimal have consistently shown excellent results. Still, if the optimal conditions can be further optimized through open and transparent cooperation, it provides the possibility to realize more profitable and sustainable tourism objects that are wide open, effective, and efficient. The government, as the main pentahelix element, is expected to become a pioneer that is expected to be able to embrace all other pentahelix elements to work together collaboratively. Budget constraints, conflicts of interest, and the fact that tourism objects have not been placed in order of priority make the realization of tourism not yet experienced optimal improvement from all sectors. Starting from the system, planning, governance to the level of control. Indeed, this has become its irony and polemic when natural resources have provided attractive tourism objects. Still, no intertwining collaborative interaction patterns then tourism objects will move slowly and will undoubtedly have an impact on ineffective sources of income of an area that is material or non-material.

\subsection{Managerial Implication}

Apart from that, highlighting the use of methods in looking at role involvement, communication patterns, and patterns of interaction between stakeholders qualitatively provide reasonable projections to be able to find gaps in the fabric of pentahelix collaboration. Meanwhile, to measure the performance of the concepts carried out by the pentahelix element, the quantitative approach through quadrants analysis and eigenvalues analysis provides a clear picture that the implementation of what factors are felt by tourism consumers regarding the application of tourism concepts and ideas that have been proclaimed by pentahelix stakeholders. Of course, the measurement and test results that have been used in this study provide proper 
measurements to measure the effectiveness of program activities and can be a reference for each pentahelix element to improve.

\section{Conclusions}

Recognized or not, the world continues to experience very dynamic and complex developments. World development does not only demand material profit but also demands equality from all sectors. It is also undeniable that strengths and weaknesses are a package that is difficult to avoid. In short, nothing is perfect in this world to carry out its roles and activities without relying on others. Pentahelix is a collection of stakeholders who together have advantages in their respective sectors. These advantages turned out to have weaknesses that these strengths and strengths were limited by specific dimensions so that adhesive was needed to unite the elements of pentahelix (academics, government, business, and media) to become a whole and influential variable in the collaboration package. This study provides a real picture that to realize a tourism program that is profitable, holistic, and sustainable requires collaboration that is wrapped with transparent and interactive communication patterns. The marketing communication concept approach combined with collaboration theory between stakeholders can project that the planning and application of programs, concepts, and ideas will work well in the future.

\section{References}

Ansell, C., \& Gash, A. (2008). Collaborative governance in theory and practice. Journal of Public Administration Research and Theory, 18(4), 543-571. https://doi.org/10.1093/jopart/mum032

Aribowo, H., Wirapraja, A., \& Putra, Y. D. (2018). Implementation of the Pentahelix Model Collaboration in Order to Develop Tourism Potential in East Java and Improve the Domestic Economy. Jurnal Mebis (Manajemen Dan Bisnis), 3(1), 31-38. https://doi.org/10.33005/mebis.v3i1.21

Barney, J. B., \& Harrison, J. S. (2018). Stakeholder Theory at the Crossroads. Business \& Society, 59(2), 203-212. https://doi.org/10.1177/0007650318796792

Berrozpe, A., Campo, S., \& Yagüe, M. J. (2019). Am I Ibiza? Measuring brand identification in the tourism context. Journal of Destination Marketing \& Management, 11(March), 240 250. https://doi.org/10.1016/j.jdmm.2018.04.005

Bharadwaj, A. (2014). Planning Internal Communication Profile for Organizational Effectiveness. IIM Kozhikode Society \& Management Review, 3(2), 183-192. https://doi.org/10.1177/2277975214542059

Björk, P. (1997). Marketing of Finnish eco-resorts. Journal of Vacation Marketing, 3(4), 303-313. https://doi.org/10.1177/135676679700300403

Burchill, A. T., \& Pavlic, T. P. (2019). Dude, where's my mark? Creating robust animal identification schemes informed by communication theory. Animal Behaviour, 154(August), 203208. https://doi.org/10.1016/j.anbehav.2019.05.013

Cárdenas, D. A., Byrd, E. T., \& Duffy, L. N. (2015). An exploratory study of community awareness of impacts and agreement to sustainable tourism development principles. Tourism and Hospitality Research, 15(4), 254-266. https://doi.org/10.1177/1467358415580359

Choi, H. S. C., \& Sirakaya, E. (2005). Measuring residents' attitude toward sustainable tourism: Development of sustainable tourism attitude scale. Journal of Travel Research, 43(4), 380-394. https://doi.org/10.1177/0047287505274651

Crosby, B. (1992). Stakeholder analysis: a vital tool for strategic managers (USAID's Implementing Policy Change Project, pp.1-6).

D’Angella, F., \& Go, F. M. (2009). Tale of two cities' collaborative tourism marketing: Towards a theory of destination stakeholder assessment. Tourism Management, 30(3), 429-440.

https://doi.org/10.1016/j.tourman.2008.07.012

Dorn, N. (2011). Reconstructing 'conflict of interest' in financial markets: Private management, public challenges, future prospects. International Journal of Law, Crime and Justice, 39(3), 161-173. https://doi.org/10.1016/j.ijlcj.2011.05.004

El-Adly, M. I. (2019). Modelling the relationship between hotel perceived value, customer satisfaction, and customer loyalty. Journal of Retailing and Consumer Services, 50(September), 322-332. https://doi.org/10.1016/j.jretconser.2018.07.007

Elias, A. A. (2017). Systems Thinking and Modelling for Stakeholder Management. IIM Kozhikode Society \& Management Review, 6(2), 123-131. https://doi.org/10.1177/2277975216681105

Emerson, K., \& Gerlak, A. K. (2014). Adaptation in collaborative governance regimes. Environmental Management, 54(4), 768-781. https://doi.org/10.1007/s00267-014-0334-7

Florek, I. (2012). Sustainable Tourism Development. Region Formation and Development Studies. Journal of Social Sciences, 8(3), 157-166. https://doi.org/10.1007/3-54025815-9 16

Fragoudaki, A., \& Giokas, D. (2016). Airport performance in a tourism receiving country: Evidence from Greece. Journal of Air Transport Management, 52(April), 80-89. https://doi.org/10.1016/j.jairtraman.2015.12.010

Freeman, R. E. (1999). Divergent stakeholder theory. Academy of Management Review, 24(2), 233-236. http://www.jstor.org/stable/259078

Freeman, R. E., Phillips, R., \& Sisodia, R. (2018). Tensions in Stakeholder Theory. Business \& Society, 59(2), 213-231. https://doi.org/10.1177/0007650318773750

Gyan, C., \& Ampomah, A. O. (2016). Effects of Stakeholder Conflicts on Community Development Projects in Kenyase. SAGE Open, 6(1), 1-8. https://doi.org/10.1177/2158244016635254

Halibas, A. S., Sibayan, R. O., \& Maata, R. L. R. (2017). The Penta Helix Model of Innovation in Oman: An Hei Perspective. Interdisciplinary Journal of Information, Knowledge \& Management, 12(2), 159-174. 
https://doi.org/10.28945/3735

Haming, M., Syaiful, A. Z., Putra, A. H. P. K., \& Murdifin, I. (2019). The Application of SERVQUAL Distribution in Measuring Customer Satisfaction of Retails Company. Journal of Distribution Science, 17(2), 25-31. https://doi.org/10.15722/jds.17.2.201902.25

Hidayat, I., \& Harto, S. (2017). Indonesia-South Korea Tourism Cooperation Relations 2015-2016. Jurnal Online Mahasiswa Bidang Ilmu Sosial Dan Ilmu Politik, 4(2), 1-15.

Hingtgen, N., Kline, C., Fernandes, L., \& McGehee, N. G. (2015). Cuba in transition: Tourism industry perceptions of entrepreneurial change. Tourism Management, 50(October), 184-193. https://doi.org/10.1016/j.tourman.2015.01.033

Indonesia Minister of Tourism. (2016). Guidelines for Sustainable Tourism Destination (pp.1-8).

Jain, D., \& Gandhi, V. P. (2016). Reforming Watershed Management Institutions for Inclusive and Sustainable Growth: Role of Institutional Interaction and Participative Decision Making. IIM Kozhikode Society \& Management Review, 5(1), 22-40. https://doi.org/10.1177/2277975215618030

Jamal, T., Taillon, J., \& Dredge, D. (2011). Sustainable tourism pedagogy and academic-community collaboration: A progressive service-learning approach. Tourism and Hospitality Research, 11(2), 133-147. https://doi.org/10.1057/thr.2011.3

Jansson, A. (2018). Rethinking post-tourism in the age of social media. Annals of Tourism Research, 69(March), 101-110. https://doi.org/10.1016/j.annals.2018.01.005

Kapera, I. (2018). Sustainable tourism development efforts by local governments in Poland. Sustainable Cities and Society, 40(October), 581-588. https://doi.org/10.1016/j.scs.2018.05.001

Kozak, M., \& Buhalis, D. (2019). Cross-border tourism destination marketing: Prerequisites and critical success factors. Journal of Destination Marketing \& Management, 14(December), ID:100392. https://doi.org/10.1016/j.jdmm.2019.100392

Kurniawan, F., Adrianto, L., Bengen, D. G., \& Prasetyo, L. B. (2019). The social-ecological status of small islands: An evaluation of island tourism destination management in Indonesia. Tourism Management Perspectives, 31(July), 136144. https://doi.org/10.1016/j.tmp.2019.04.004

Kusuma, A. H. P., Rina, R., \& Syam, A. H. (2018). The Main Role of Locus of Control and Professional Ethics on Lecturer's Performance (Indonesian Lecturer Empirical Study). International Review of Management and Marketing, 8(5), 9-17.

Laplume, A. O., Sonpar, K., \& Litz, R. A. (2008). Stakeholder Theory: Reviewing a Theory That Moves Us. Journal of Management, 34(6), 1152-1189. https://doi.org/10.1177/0149206308324322

Lee, J. W., \& Syah, A. M. (2018). Economic and Environmental Impacts of Mass Tourism on Regional Tourism Destinations in Indonesia. Journal of Asian Finance, Economics and Business, 5(3), 31-41. http://doi.org/10.13106/jafeb.2018.vol5.no3.31

Li, C., Guo, S., Wang, C., \& Zhang, J. (2019). Veni, vidi, vici: The impact of social media on virtual acculturation in tourism context. Technological Forecasting and Social Change, 145(August), 513-522. https://doi.org/10.1016/j.techfore.2019.01.013

Martin, S. L., Javalgi, R. G., \& Ciravegna, L. (2020). Marketing capabilities and international new venture performance: The mediation role of marketing communication and the moderation effect of technological turbulence. Journal of Business Research, 107(February), 25-37. https://doi.org/10.1016/j.jbusres.2019.09.044

Mashur, R., Gunawan, B. I., Fitriany, Ashoer, M., Hidayat, M., \& Putra, A. H. P. K. (2019). Moving from Traditional to Society 5.0: Case study by Online Transportation Business. Journal of Distribution Science, 17(9), 93-102. http://dx.doi.org/10.15722/jds.17.9.201909.93

McComb, E. J., Boyd, S., \& Boluk, K. (2016). Stakeholder collaboration: A means to the success of rural tourism destinations? A critical evaluation of the existence of stakeholder collaboration within the Mournes, Northern Ireland. Tourism and Hospitality Research, 17(3), 286-297. https://doi.org/10.1177/1467358415583738

Murdifin, I., Pelu, M. F. A. R., Putra, A. A. H. P. K., Arumbarkah, A. M., Muslim, M., \& Rahmah, A. (2018). Environmental Disclosure as Corporate Social Responsibility: Evidence from the Biggest Nickel Mining in Indonesia. International Journal of Energy Economics and Policy, 9(1), 115-122.

Mustafa, A. M. M. (2019). Contribution of Tourism and Foreign Direct Investment to Gross Domestic Product: Econometric Analysis in the Case of Sri Lanka. Journal of Asian Finance, Economics and Business, 6(4), 109-114. https://doi.org/10.13106/jafeb.2019.vol6.no4.109

Pablé, A. (2019). Is a general non-ethnocentric theory of human communication possible? An integrationist approach. Lingua, 230. https://doi.org/10.1016/j.lingua.2019.102735

Park, S., Hahn, S., Lee, T., \& Jun, M. (2018). Two factor model of consumer satisfaction: International tourism research. Tourism Management, 67(August), 82-88. https://doi.org/10.1016/j.tourman.2018.01.007

Porcu, L., del Barrio-García, S., Kitchen, P. J., \& Tourky, M. (2019). The antecedent role of a collaborative vs. a controlling corporate culture on firm-wide integrated marketing communication and brand performance. Journal of Business Research. (Article in press) https://doi.org/10.1016/j.jbusres.2019.10.049

Poudel, S., Nyaupane, G. P., \& Budruk, M. (2014). Stakeholders' Perspectives of Sustainable Tourism Development: A New Approach to Measuring Outcomes. Journal of Travel Research, 55(4), 465-480. https://doi.org/10.1177/0047287514563166

Ramón, M., Herrera, G., Sasidharan, V., Daniel, L., Herrera, A., Alberto, J., \& Hernández, Á. (2018). Quality and sustainability of tourism development in Copper Canyon, Mexico: Perceptions of community stakeholders and visitors. Tourism Management Perspectives, 27(1210), 91-103. https://doi.org/10.1016/j.tmp.2018.05.003

Soemaryani, I. (2016). Pentahelix model to increase tourist visit to bandung and its surrounding areas through human resource development. Academy of Strategic Management Journal, 15(3), 249-259.

Stylidis, D., Belhassen, Y., \& Shani, A. (2014). Three Tales of a 
City: Stakeholders' Images of Eilat as a Tourist Destination. Journal of Travel Research, 54(6), 702-716. https://doi.org/10.1177/0047287514532373

Suryaningnum, D. H., Hastuti, S., \& Suhartini, D. (2013). Accounting Student and Lecturer Ethical Behavior: Evidence from Indonesia. Business Education \& Accreditation, 5(1), $31-40$.

Tan, G. W.H., Lee, V.-H., Hew, J.-J., Ooi, K.-B., \& Wong, L.-W. (2018). The interactive mobile social media advertising: An imminent approach to advertise tourism products and services? Telematics and Informatics, 35(8), 2270-2288. https://doi.org/10.1016/j.tele.2018.09.005

Theodoulidis, B., Diaz, D., Crotto, F., \& Rancati, E. (2017). Exploring corporate social responsibility and financial performance through stakeholder theory in the tourism industries. Tourism Management, 62(October), 173-188. https://doi.org/10.1016/j.tourman.2017.03.018

Thomson, A. M., \& Perry, J. L. (2006). Collaboration processes: Inside the black box. Public Administration Review, 66(November), 20-32. https://doi.org/10.1111/j.1540-6210.2006.00663.x

Tyrrell, T., Paris, C. M., \& Biaett, V. (2012). A Quantified Triple Bottom Line for Tourism: Experimental Results. Journal of Travel Research, 52(3), 279-293. https://doi.org/10.1177/0047287512465963

Wang, W., Liu, J., \& Innes, J. L. (2019). Conservation equity for local communities in the process of tourism development in protected areas: A study of Jiuzhaigou Biosphere Reserve, China. World Development, 124(December), ID: 104637. https://doi.org/10.1016/j.worlddev.2019.104637

Wondirad, A., \& Ewnetu, B. (2019). Community participation in tourism development as a tool to foster sustainable land and resource use practices in a national park milieu. Land Use Policy, 88(November), ID:104155. https://doi.org/10.1016/j.landusepol.2019.104155

$\mathrm{Wu}, \mathrm{G}$. (2018). Official websites as a tourism marketing medium: A contrastive analysis from the perspective of appraisal theory. Journal of Destination Marketing \& Management, 10(December), 164-171. https://doi.org/10.1016/j.jdmm.2018.09.004

Yousaf, S., \& Xiucheng, F. (2018). Halal culinary and tourism marketing strategies on government websites: A preliminary analysis. Tourism Management, 68(October), 423-443. https://doi.org/10.1016/j.tourman.2018.04.006

Yu, C. P., Chancellor, H. C., \& Cole, S. T. (2011). Measuring residents' attitudes toward sustainable tourism: A reexamination of the sustainable tourism attitude scale. Journal of Travel Research, 50(1), 57-63. https://doi.org/10.1177/0047287509353189

Yuningsih, T., Darmi, T., \& Sulandari, S. (2019). Pentahelix Model in Tourism Development in Semarang City. Journal of Public Sector Innovations, 3(2), 84-93. http://dx.doi.org/10.26740/jpsi.v3n2.p84-93

Yusuf, M., Nurhilalia, \& Putra, A. H. P. K. (2019). The Impact of Product Quality, Price, and Distribution on Satisfaction and Loyalty. Journal of Distribution Science, 17(10), 17-26. http://dx.doi.org/10.15722/jds.17.10.201910.17 


\section{Appendix}

Appendix 1: Measurement of Variables

\begin{tabular}{|c|c|c|}
\hline Variables & Construct & Code \\
\hline $\begin{array}{c}\text { Marketing } \\
\text { Communication }\end{array}$ & $\begin{array}{l}\text { - The local government is active in promoting the destination of Sitiwinangun Tourism Village to } \\
\text { prospective tourists } \\
\text { - Tourism promotion of Sitiwinangun Tourism Village is often found in various mass-media /digital) } \\
\text { Ease of support for access to tourist sites in Sitiwinangun Tourism Village } \\
\text { - Support tourist facilities such as hotels and restaurants } \\
\text { Cleanliness and security guarantees during the tour }\end{array}$ & $\begin{array}{ll}\text { - } & \mathrm{MCom} 1 \\
\text { - } & \mathrm{MCom} 2 \\
\text { - } & \mathrm{MCom} 3 \\
\text { - } & \mathrm{MCom} 4 \\
\text { - } & \mathrm{MCom} 5 \\
\text { - } & \mathrm{MCom} 6\end{array}$ \\
\hline $\begin{array}{l}\text { Tourism } \\
\text { Satisfaction }\end{array}$ & $\begin{array}{l}\text { - Satisfied with food includes cleanliness, taste, and serving of food during the trip } \\
\text { - Satisfied with the availability of proper and good transportation } \\
\text { Satisfied with the price (product/hotel) at the tourist location } \\
\text { - Satisfied with community hospitality and service at tourist sites } \\
\text { - Satisfied with facilities (number of hotels/parking/security) at tourist sites tourist } \\
\text { - Increase personal value (prestige, hedonic, quality value) }\end{array}$ & $\begin{array}{ll}- & \text { TS1 } \\
- & \text { TS2 } \\
\text { - } & \text { TS3 } \\
\text { - } & \text { TS4 } \\
\text { - } & \text { TS5 } \\
\text { - } & \text { TS6 } \\
\text { - } & \text { TS7 }\end{array}$ \\
\hline
\end{tabular}

Appendix 2: Informant of Pentahelix element $(\mathrm{N}=17)$ and Respondent/Tourism $(\mathrm{N}=30)$

\begin{tabular}{|c|c|c|c|c|}
\hline Academics (A) & Business (B) & Community - C & Government (G) & Media (M) \\
\hline $\begin{array}{l}\text { Craft Study Program Faculty } \\
\text { of Fine Arts and Design, } \\
\text { Bandung Institute of } \\
\text { Technology (ITB) }\end{array}$ & $\begin{array}{c}\text { Indonesian Tourism } \\
\text { Performers } \\
\text { Association (ASPPI) } \\
\text { DPC region III West } \\
\text { Java }\end{array}$ & $\begin{array}{l}\text { The Sultanate of } \\
\text { Cirebon Regency }\end{array}$ & $\begin{array}{l}\text { Ministry of SME's. Chemical, } \\
\text { Clothing, Crafts and Various } \\
\text { Industries, Ministry of Industry, } \\
\text { Jakarta }\end{array}$ & $\begin{array}{l}\text { Online Media About } \\
\text { Cirebon }\end{array}$ \\
\hline $\begin{array}{c}\text { Tourism Travel Study } \\
\text { Program, YAPARI Bandung } \\
\text { College of Economics and } \\
\text { Tourism (STIEPAR) }\end{array}$ & $\begin{array}{l}\text { Regional } 3 \text { Corporate } \\
\text { Development Center } \\
\text { (CDC) Telkom } \\
\text { Bandung }\end{array}$ & $\begin{array}{l}\text { Cirebon Business } \\
\text { Forum }\end{array}$ & $\begin{array}{c}\text { Department of Industry and Trade } \\
\text { Cirebon Regency }\end{array}$ & $\begin{array}{c}\text { Radar Cirebon Group } \\
\text { (Newspapers and } \\
\text { Television) }\end{array}$ \\
\hline $\begin{array}{l}\text { Community Service } \\
\text { Institution Universitas } \\
\text { Gunung Jati }\end{array}$ & null & $\begin{array}{l}\text { Sitiwinangun Tourism } \\
\text { Awareness Group }\end{array}$ & $\begin{array}{c}\text { Department of Culture, Tourism, } \\
\text { Youth, and Sports } \\
\text { (Disbudparpora) Cirebon Regency }\end{array}$ & null \\
\hline null & null & $\begin{array}{c}\text { Karang Taruna } \\
\text { Sitiwinangun Village }\end{array}$ & $\begin{array}{c}\text { Regional Development Planning } \\
\text { and Research Agency } \\
\text { (Bappelitbangda) Cirebon } \\
\text { Regency. }\end{array}$ & null \\
\hline null & null & visitor & Sitiwinangun Village Government & Null \\
\hline Respondent & \multicolumn{2}{|c|}{ n } & \multicolumn{2}{|l|}{$\%$} \\
\hline $\begin{array}{l}\text { Gender } \\
\text { - } \quad \text { Male } \\
\text { - } \quad \text { Female }\end{array}$ & \multicolumn{2}{|c|}{$\begin{array}{l}15 \\
15 \\
\end{array}$} & \multicolumn{2}{|l|}{$\begin{array}{l}50 \\
50\end{array}$} \\
\hline $\begin{array}{cc}\text { Age (years) } \\
\text { - } & 15-24 \\
\text { - } & 25-34 \\
\text { - } & 35-44 \\
\text { - } & 45-54 \\
\text { - } & 55-54\end{array}$ & \multicolumn{2}{|c|}{$\begin{array}{l}7 \\
7 \\
6 \\
5 \\
5\end{array}$} & \multicolumn{2}{|l|}{$\begin{array}{c}23,3 \\
23,3 \\
20 \\
16.6 \\
16.6\end{array}$} \\
\hline $\begin{array}{c}\text { Total of Visit to Tourism } \\
\text { Vilage of Sitiwinangun } \\
\qquad \quad 1^{\text {st }} \text { time } \\
-\quad \text { More } 2^{\text {nd }} \text { time }\end{array}$ & \multicolumn{2}{|c|}{$\begin{array}{c}2 \\
28\end{array}$} & \multicolumn{2}{|l|}{$\begin{array}{c}6.6 \\
93.4\end{array}$} \\
\hline
\end{tabular}


Appendix 3: Effect and Interest of Pentahelix Tourism stakeholders

\begin{tabular}{|c|c|c|c|}
\hline & Stakeholder & Effect & Interest \\
\hline 1 & Academics & $\begin{array}{l}\text { Provide knowledge and innovation of local } \\
\text { products by adding distinctive artistic elements, } \\
\text { such as mega cloudy accents. } \\
\text { Assist in the preparation of institutions, } \\
\text { attractions, amenities, and accessibility of tourist } \\
\text { villages. }\end{array}$ & $\begin{array}{l}\text { - The implementation of the tri dharma (Lecturer Workload) } \\
\text { of tertiary institutions, namely education, research, and } \\
\text { community service. } \\
\text { - Academic pride. } \\
\text { - Implementation of assistance programs to improve } \\
\text { products resulting from cooperation with the government. } \\
\text { Partnership with other tourism stakeholders, such as the } \\
\text { government and the community. }\end{array}$ \\
\hline 2 & Business & $\begin{array}{l}\text { Tourism village as a destination for tourists and } \\
\text { provide economic value for the community. } \\
\text { Become a promotional event for other travel } \\
\text { agents. } \\
\text { Provide access to direct assistance, such as } \\
\text { training and construction of public facilities. } \\
\text { - Corporate CSR funds in the soft venture capital } \\
\text { loan program for the community }\end{array}$ & $\begin{array}{l}\text { - Establish cooperation with the community and village } \\
\text { tourism managers. } \\
\text { It's having a new alternative tourist destination in Cirebon } \\
\text { Regency that presents the complexity of attractions in the } \\
\text { form of art, culture, history, and religion. }\end{array}$ \\
\hline 3 & Community & $\begin{array}{l}\text { - Encouraging the inclusion of several investors and } \\
\text { access to cooperation that they do in private and } \\
\text { public figures. } \\
\text { Mapping, exploring, and planning village } \\
\text { potentials to be developed as a form of } \\
\text { community empowerment. }\end{array}$ & $\begin{array}{l}\text { Emphasize the community and the outside world that the } \\
\text { tourism village is a locomotive of empowerment with } \\
\text { economic value, preserving the environment and local } \\
\text { culture. } \\
\text { - Self-actualization and local community pride in cultural } \\
\text { ownership. } \\
\text { - Collaboration with all levels of society and stakeholders. }\end{array}$ \\
\hline 4 & Government & $\begin{array}{l}\text { Regulators, facilitators, and motivators in the form } \\
\text { of work programs for the development of local } \\
\text { village potentials so that the socio-cultural } \\
\text { potential, such as historical values, maintained the } \\
\text { culture, and economic benefits are felt directly by } \\
\text { the community. } \\
\text { Empowerment in the form of training and } \\
\text { community assistance to increase the potential of } \\
\text { tourism villages. }\end{array}$ & $\begin{array}{l}\text { Carry out the government's task to provide guidance and } \\
\text { development to the people of Cirebon Regency. }\end{array}$ \\
\hline 5 & Media & $\begin{array}{l}\text { - Promote tourist sites and their potential to the } \\
\text { public. }\end{array}$ & $\begin{array}{l}\text { Source of news content to the public through print, } \\
\text { electronic, and regional online news media }\end{array}$ \\
\hline
\end{tabular}




\section{Appendix 4:}

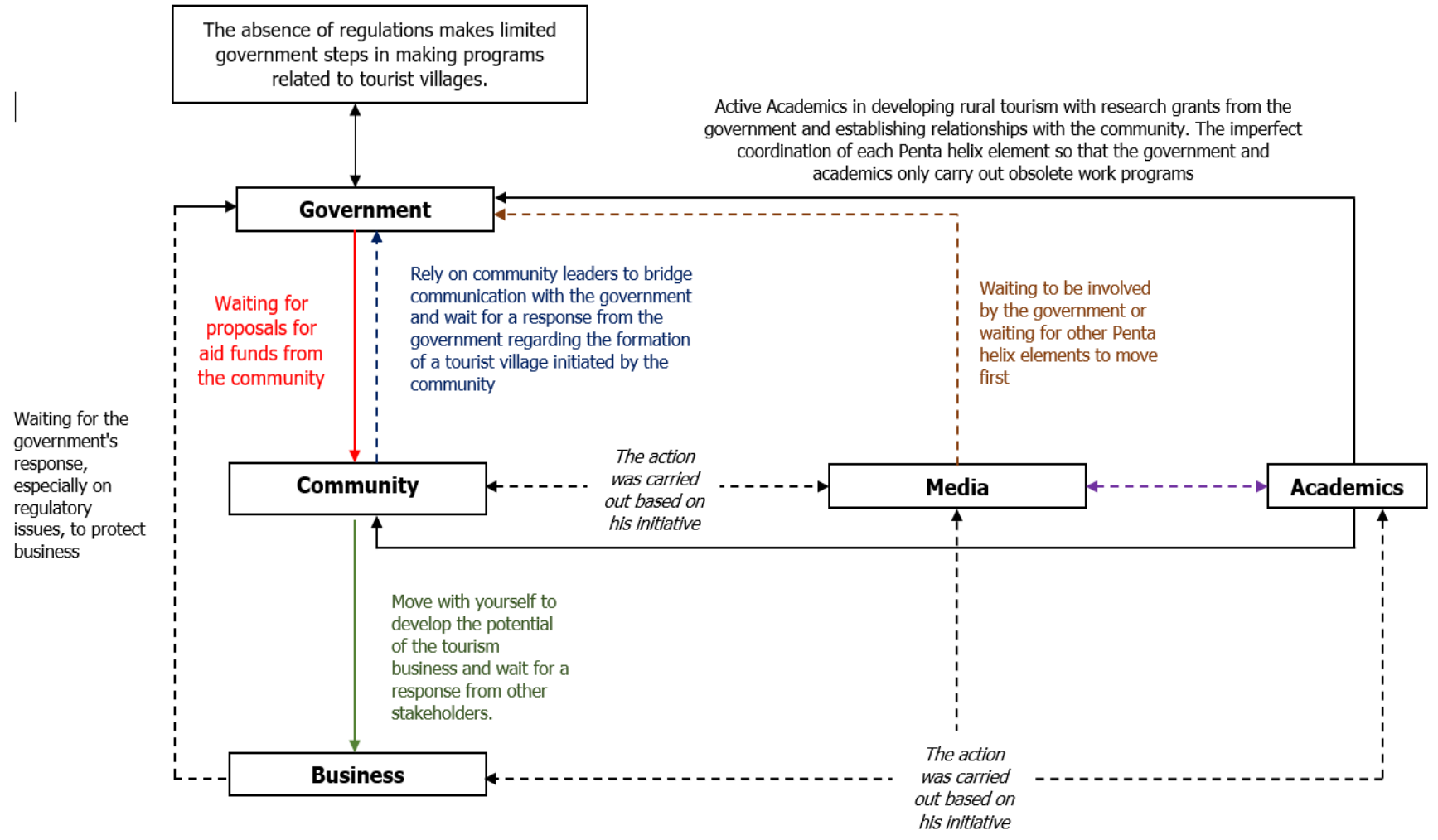

Figure 1: Factors affecting communication between pentahelix elements 